\title{
FLEKSIBILITAS PENGELOLAAN KELAS DALAM PENDIDIKAN (Ekspektasi Efektivitas Keberhasilan Proses Pembelajaran)
}

\author{
Abdul Ghofar \\ Fakultas Ilmu Tarbiyah dan Keguruan \\ Institut Agama Islam Negeri Syekh Nurjati Cirebon \\ email: abdulghofar12345@gmail.com
}

\begin{abstract}
Abstrak
Upaya guru mengelola kelas adalah suatu kegiatan atau usaha dengan menggunakan segala kekuatan yang ada dalam mengatasi suatu masalah guna menciptakan dan mempertahankan suasana/kondisi kelas yang menunjang program pengajaran dengan jalan menciptakan dan mempertahankan motivasi siswa untuk selalu ikut terlibat dan berperan serta dalam proses pendidikan di sekolah agar tecapai suatu tujuan yang optimal. Pengelolaan kelas yang baik, yang dilakukan oleh guru akan dapat memberikan kenyamanan dalam pembelajaran siswa, sehingga prosesnya akan berjalan secara maksimal. Hal inilah yang ingin dicapai dalam pengelolaan kelas. Karena pengelolaan kelas merupakan cara untuk meningkatkan efektivitas proses pembelajaran.

Pembelajaran merupakan komunikasi dua arah, dimana kegiatan guru sebagai pendidik harus mengajar dan murid sebagai terdidik yang belajar. Efektivitas pembelajaran merupakan komunikasi dua arah, dimana kegiatan guru sebagai pendidik harus mengajar dan murid sebagai terdidik yang belajar. Karena pengelolaan kelas merupakan cara untuk meningkatkan efektivitas proses pembelajaran. Untuk meningkatkan efektivitas proses pembelajaran dalam pengelolaan kelas, ada beberapa upaya yang harus dipersiapkan oleh guru yaitu aktif diri (sering membaca) agar mampu menguasai materi secara matang, melek informasi (pandai mencari informasi yang baru) agar tidak ketinggalan zaman, komitmen kerja (ikhlas, rajin dan tidak mengeluh), keteladanan karena guru adalah contoh bagi siswa-siwanya.
\end{abstract}

Kata Kunci: Pengelolaan, Keberhasilan, Pembelajaran 


\section{A. Pendahuluan}

Pendidikan dalam sejarah peradaban manusia merupakan salah satu komponen kehidupan yang paling urgen. Aktifitas ini telah dimulai sejak manusia pertama ada di dunia sampai berakhirnya kehidupan di muka bumi ini. ${ }^{1}$ Upaya meningkatkan kualitas pendidikan terus menerus dilakukan, baik secara konvensional maupun inovatif. Pendidikan dapat dirumuskan sebagai usaha yang terencana dan sungguh-sungguh dari suatu generasi yang dianggap telah dewasa untuk mentransformasikan ilmu pengetahuannya, nilai-nilai dan budaya masyarakatnya kepada generasi yang belum dewasa.Untuk meningkatkan mutu atau kualitas pendidikan diperlukan peningkatan dan penyempurnaan pendidikan yang berkaitan erat dengan peningkatan kualitas proses belajar mengajar secara operasional yang berlangsung di dalam kelas.

Guru mempunyai peranan yang penting. Pada awal memberikan penjelasan tentang peran-peran yang akan ditampilkan dan tujuan-tujuan yang hendak dicapai. ${ }^{2}$ Guru yang ideal dituntut keseimbangan antara unsur fisik, mental, dan rohani, guru tidak hanya bertanggung-jawab sekedar tahu materi yang akan diajarkan saja tetapi ia juga harus mampu mengelola kelas yang baik agar tercapai tujuan pembelajaran yang diinginkan.Guru merupakan salah satu faktor penting dalam pendidikan, terutama dalam proses pembelajaran. Guru sangat besar pengaruhnya terhadap perkembangan kepribadian anak didik. Agar dapat menjalankan tugasnya dengan baik dan sempurna serta menguasai ilmu yang akan disampaikan kepada anak didik guru hendaknya memiliki keahlian khusus di bidangnya.

Abdorrakhman Gintings ${ }^{3}$ berpendapat bahwa pengelolaan kelas dapat diartikan sebagai upaya dan tindakan yang dilakukan oleh guru untuk menciptakan suasana belajar dan pembelajaran yang kondusif bagi tercapainya tujuan pembelajaran. Salah satu kegiatan pendidikan adalah penyelenggaraan belajar mengajar. Pendidikan merupakan bimbingan atau pertolongan yang di berikan oleh orang dewasa kepada perkembangan anak untuk mencapai kedewasaan dengan tujuan agar mempu melaksanakan tugas hidupnya sendiri tidak dengan bantuan orang lain. pendidikan sebagai sebuah sistem terdiri dari beberapa komponen yang antara satu dan lainnya saling berkaitan. Begitu juga dalam proses belajar yang terpenting adalah proses bukan hasil yang diperolehnya.

M. Sobry Sutikno ${ }^{4}$ mengemukakan ada beberapa faktor yang mempengaruhi proses belajar, baik faktor yang datang dari diri individu yang belajar (internal) maupun faktor yang berasal dari luar (eksternal) atau bisa saja gabungan dari kedua faktor tersebut. Oleh karena itu, diperlukan

\footnotetext{
${ }^{1}$ Suharsimi Arikunto, Pengelolaan Kelas dan Siswa Sebuah Pendekatan Evaluatif (Jakarta: Rajawali Press, 1992),

${ }^{2}$ Oemar Hamalik,Perencanaan Pengajaran Berdasarkan Pendekatan Sistem (Jakarta: PT. BumiAksara, 2009), 200.

${ }^{3}$ M. Abdorrakhman Gintings, Esensi Praktis Belajar \& Pembelajaran (Bandung: Humaniora, 2008), 173.

${ }^{4}$ M. Sobry Sutikno, Belajar dan Pembelajaran (Bandung: Prospect, 2008), 14.
} 
pengelolaan kelas yang baik sehingga tujuan pembelajaran dapat tercapai. Karenanya, pengelolaan kelas memegang peranan yang sangat menentukan dalam proses pembelajaran. Suharsimi Arikunto, ${ }^{5}$ berpendapat bahwa pengelolaan kelas adalah suatu usaha yang dilakukan oleh penanggungjawab kegiatan belajar-mengajar atau yang membantu dengan maksud agar dicapainya kondisi yang optimal, sehingga dapat terlaksana kegiatan belajar seperti yang diharapkan.

Syaiful Bahri Djamarah ${ }^{6}$ berpendapat bahwa pengelolaan kelas merupakan salah satu tugas guru yang tidak pernah ditinggalkan. Guru selalumengelola kelas ketika dia melaksanakan tugasnya. Pengelolaan kelas dimaksudkan untuk menciptakan lingkungan belajar yang kondusif bagi anak didik sehingga tercapai tujuan pengajaran secara efektif dan efisien. Ketika kelas terganggu, guru berusaha mengembalikannya agar tidak menjadi penghalang bagi proses belajar mengajar.

Dari uraian diatas jelas bahwa program kelas akan berkembang bilamana guru/wali kelas mendayagunakan secara maksimal potensi kelas yaitu dengan memberikan kesempatan seluas-luasnya kepada setiap personal kelas baik itu guru sendiri maupun siswa sehingga proses kegiatan belajar mengajar berjalan secara efektif dan efisien. Potensi kelas terdiri dari tiga unsur yaitu guru, siswa, dan proses atau dinamika kelas.

Adapun kegiatan pengeloaan kelas dapat meliputi dua hal, yaitu (1) pengelolaan kelas yang menyangkut siswa, dan (2) pengelolaan fisik (ruangan, perabotan, alat belajar). Kedua hal tersebut perlu dikelola secara baik dalam rangka menghasilkan suasana yang kondusif bagi terciptanya pembelajaran yang baik pula. ${ }^{7}$

Made Pidarta ${ }^{8}$ berpendapat bahawa pengelolaan kelas dapat dideskripsikan sebagai proses mengorganisasi dan mengkordinasi kemauan murid untuk menyelesaikan tujuan pendidikannya. Namun dalam pelaksanaan pengelolaan kelas, guru seringkali menemukan hambatan-hambatan. Masalah atau hambatan yang dihadapi oleh guru yakni dari faktor peserta didik, faktor keluarga yang broken home, faktor fasilitas sekolah, dan dari guru sendiri.

Proses pembelajaran merupakan inti dari proses pendidikan formal dengan guru sebagai pemeran utama. Guru sangat menentukan suasana pembelajarandi dalam kelas. Guru yang kompeten akan lebih mampu dalam menciptakan lingkungan belajar yang efektif dan efisien di dalam kelas. Pembelajaran yang efektif memudahkan siswa belajar sesuatu yang bermanfaat, seperti fakta keterampilan, nilai, konsep, cara hidup serasi dengan sesama, atau sesuatu hasil belajar yang diinginkan sehingga hasil

\footnotetext{
${ }^{5}$ Suharsimi Arikunto, Pengelolaan Kelas dan Siswa Sebuah Pendekatan Evaluatif (Jakarta: Rajawali Press, 1992), 67.

${ }^{6}$ Syaiful Bahri Djamarah \& Aswan Zain, Strategi Belajar Mengajar (Jakarta: PT. Rineka Cipta, 2010), 174.
}

${ }^{7}$ Ahmad Fauzi,Manajemen Pembelajaran (Yogyakarta: Deepublish, 2013) 246.

${ }^{8}$ Pidarta Made, Pengelolaan Kelas (Surabaya: Usaha Nasional, 2010), 11-12. 
belajar siswa berada pada tingkat yang optimal. Keberhasilan tersebut, dipengaruhi banyak faktor terutama terletak pada pengajar(guru) dan yang diajar (siswa), yang berkedudukan sebagai pelaku dan subyek dalam proses tersebut. ${ }^{9}$

Guru adalah pendidik professional dengan tugas utama mendidik, mengajar, membimbing, mengarahkan, melatih, dan mengevaluasi peserta didik pada pendidikan anak usia dini jalur pendidikan formal, pendidikan dasar, dan pendidikan menengah.Tugas guru yang paling pertama dan utamaadalah mengajar dalam pengertian menata lingkungan agar terjadi kegiatan belajar pada peserta didik. Tugas guru dalam pembelajaran tidak terbatas pada penyampaian informasi kepada peserta didik. Sesuai kemajuan dan tuntutan zaman, guru harus memiliki kemampuan untuk memahami peserta didik dengan berbagai keunikan agar mampu membantu mereka dalam menghadapi kesulitan belajar. Oleh karena itu, guru dituntut memahami berbagai model pembelajaran yang efektif agar dapat membimbing peserta didik secara optimal.

Usaha guru dalam menciptakan kondisi yang diharapkan akan efektif apabila lingkungan atau iklim belajar yang kondusif, iklim belajar yang kondusif harus ditunjang oleh berbagai fasilitas belajar yang menyenangkan, seperti: sarana, laboratorium, pengaturan lingkungan, penampilan, dan sikap guru, hubungan yang harmonis antara peserta didik dengan guru dan diantara peserta didik itu sendiri. Iklim belajar yang menyenangkan akan membangkitkan semangat dan menumbuhkan aktivitas serta kreativitas peserta didik. ${ }^{10}$ Pengelolaan kelas yang efektif merupakan prasyarat mutlak bagi terjadinya proses interaksi edukatif yang efektif.

Oleh karena itu, pengelolaan sekolah perlu menciptakan suasana gembira atau menyenangkan di lingkungan sekolah melalui pengelolaan kelas, karena,dengan menjalin keakraban antara guru-siswa, maka guru dapat mengarahkan siswa dengan lebih mudah untuk mendorong dan memotivasi semangat belajar siswa. Disamping itu, juga efektivitas belajar dapat ditingkatkan melalui berabagai upaya. Pembelajaran menyenangkan satu diantara cara yang dapat dilakukan untuk mencapai efektivitaspemebelajaran. Menjelaskan bahwa pembelajaran menyenagkan adalah pembelajaran dimana interaksi antara guru dan siswa, lingkungan fisik, dan suasana memberikan peluang terciptanya kondisi yang kondusif untuk belajar. ${ }^{11}$

Proses pembelajaran sering kali digunakan berbagai istilah yang pada dasarnya dimaksudkan untuk menjelaskan cara, tahapan, atau pendekatan yang dilakukan seoarang guru untuk mencapai tujuan pembelajaran. Proses pembelajaran merupakan serangkaian kegiatan yang dilaksanakan oleh guru

${ }^{9} \mathrm{M}$. Sobry Sutikno, Belajar dan Pembelajaran ....... 173.

${ }^{10}$ Abdul Madjid, Perencanaan Pembelajaran Mengembangkan Standar Kompetensu Guru (Bandung: Remaja Rosdakarya, 2011), 165.

${ }^{11}$ Darmasya, Strategi Pembelajaran Menyenangkan Dengan Humor (Jakarta: PT. Bumi Aksara, 2010) 24-25. 
dan siswa dengan memanfaatkan sarana yang tersedia untuk memperoleh hasil belajar secara optimal. Jadi, prosespembelajaran dapat terwujud dengan baik apabila ada interaksi antara guru dan siswa, sesama siswa atau dengan sumber belajar lainnya. Dengan kata lain belajar dikatakan efektif apabila terjadi interaksi yang cukup maksimal dan hasil belajar optimal.

Proses interaksi ini merupakan proses interaksi belajar mengajar. Guru siswa dan materi pelajaran adalah tiga unsur utama yang terlibat langsung dalam proses ini agar tujuan pembelajaran tercapai. Selain unsur utama, unsur lain yang terlibat adalah media. Dengan demikian interaksi belajar mengajar dapat didefinisikan sebagai pendekatan khusus untuk mencapai tujuan pembelajaran.

Dengan adanya pengelolaan kelas ini maka siswa akan termotivasi dalam mengikuti proses pembelajaran yang pada khususnya merupakan modal penting bagi jernihnya pikiran dalam mengikuti pelajaran, sehingga anak merasa nyaman dan antusias. Oleh karena itu, penulis merumuskan permasalahan tentang bagaimana proses pembelajaranyang kondusif dan rekreaktifuntuk mengembangkan potensi kreatifitasnya sehingga proses pembelajaran menjadi efektif?

\section{B. Pengelolaan Kelas: Upaya Mengukur Keberhasilan Proses Pembelajaran}

Upaya sangat berkaitan erat dengan penggunaan sarana dan prasarana dalam menunjang kegiatan pengelolaan kelas, agar berhasil maka digunakanlah suatu cara, metode dan alat penunjang yang lain. Upaya adalah suatu kegiatan atau usaha dengan menggunakan segala kekuatan yang ada dalam mengatasi suatu masalah. Upaya dalam mengukur keberhasilan proses pembelajaran dalam mengelola kelas sangat berkaitan dengan guru.

Guru secara bahasa adalah orang yang menyampaikan ilmu pengetahuan. Guru adalah pendidik professional dengan tugas utama mendidik, mendidik, mengajar, membimbing, mengarahkan, melatih, dan mengevaluasi peserta didik pada pendidikan anak usia dini jalur pendidikan formal, pendidikan dasar, dan pendidikan menengah.

Jadi guru adalah orang dewasa yang secara sadar bertanggung jawab dalam mendidik, mengajar, dan membimbing peserta didik. Orang yang disebut guru adalah orang yang memiliki kemampuan merancang progam pembelajaran serta mampu menata dan mengelola kelas agar peserta didik dapat belajar dan pada akhirnya dapat mencapai tingkat kedewasaan sebagai tujuan akhir proses pembelajaran.

Mengelolamenurut Bambang Sarwiji, ${ }^{12}$ adalah kelola:mengelola didefinisikan sebagai mengurus sesuatu. Mengelola merupakan terjemahan dari kata "Management".Maka istilah Inggris tersebut kemudiandi Indonesiakan menjadi "manajemen". Artidari manajemen adalah pengelolaan usaha, penyelenggaraan, kepengurusan, ketata-laksanaan sumber daya secara efektif untuk mencapai sarana yang diinginkan.Maka menurut Suharsimi

\footnotetext{
${ }^{12}$ Bambang Sarwiji,Kamus Pelajar Bahasa Indonesia (Ganeca Exact, 2006), 383.
} 
Arikunto, (1992:8) ${ }^{13}$ mengelola/manajemen adalah penyelenggaraan atau pengurusan agar sesuatu yang dikelola dapat berjalan dengan lancar, efektif dan efisien.

Pupuh Fathurrohman \& Sobry Sutikno ${ }^{14}$ berpendapat bahwa pengelolaan kelas merupakan usaha yang dengan sengaja dilakukan oleh guru agar anak didik dapat belajar efektif dan efisien guna mencapai tujuan pembelajaran.

Abuddin Nata ${ }^{15}$ berpendapat bahwa pengelolaan kelas merupakan kegiatan yang berupaya menciptakan dan mempertahankan kondisi yang optimal bagi terjadinya proses belajar mengajar.

Suharsimi Arikunto ${ }^{16}$ berpendapat bahwapengelolaan kelas adalah suatu usaha yang dilakukan oleh penanggung-jawab kegiatan belajarmengajar atau yang membantu dengan maksud agar dicapainya kondisi yang optimal, sehingga dapat terlaksana kegiatan belajar seperti yang diharapkan.

Syaiful Bahri Djamarah \& Aswan Zain ${ }^{17}$ berpendapat bahwa pengelolaan kelas adalah keterampilan guru untuk menciptakan dan memelihara kondisi belajar yang optimal dan mengembalikannyabila terjadi gangguan dalam proses belajar mengajar.

Pengelolaan kelas merupakan upaya mengelola siswa di dalam kelas yang dilakukan untuk menciptakan dan mempertahankan suasana/kondisikelas yang menunjang program pengajaran seperti progam tahunan, progam semester yang telah dipersiapkan oleh guru ataupun ikut partisipasi dalam kegiatan lomba-lomba pendidikan tingkat kabupaten, propinsi, nasional, maupun internasional dengan jalan menciptakan dan mempertahankan motivasi siswa untuk selalu ikut terlibat dan berperan serta dalam proses pendidikan di sekolah..

Jadi upaya guru mengelola kelas adalahsuatu kegiatan atau usaha dengan menggunakan segala kekuatan yang ada dalam mengatasi suatu masalah guna menciptakan dan mempertahankan suasana/kondisi kelas yang menunjang program pengajaran dengan jalan menciptakan dan mempertahankan motivasi siswa untuk selalu ikut terlibat dan berperan serta dalam proses pendidikan di sekolah agar tecapai suatu tujuan yang optimal.

Adapun tujuan pengelolaan kelas menurut Ahmad Fauzi, ${ }^{18}$ adalah agar setiap anak di kelas dapat bekerja dengan tertib sehingga tercapai tujuan pengajaran secara efektif dan efisien.Sedangkan menurut Pupuh Fathurrahman \& M. Sobry Sutikno, ${ }^{19}$ secara umum tujuan pengelolaan kelas

\footnotetext{
${ }^{13}$ Suharsimi Arikunto, Pengelolaan Kelas ............., 8.

${ }^{14}$ Pupuh Fathurrahman \& Sobry Sutikno, Strategi Belajar Mengajar Melalui Konsep Umum \& Konsep Islami(Bandung: Refika Sditama, 2011), 104.

${ }^{15}$ Abuddin Natta, Persepektif Islam Tentang Strategi Pembelajaran (Jakarta: Prenada Media Group, 2011), 340.

${ }^{16}$ Suharsimi Arikunto, Pengelolaan Kelas.... 67.

${ }^{17}$ Syaiful Bahri Djamarah \& Aswan Zain, Strategi Belajar Mengajar (Jakarta: PT. Rineka Cipta, 2010), 173.

${ }^{18}$ Ahmad Fauzi, Manajemen Pembelajaran (Yogyakarta: Deepublish, 2013), 246.

${ }^{19}$ Pupuh Fathurrahman \& M. Sobry Sutikno, Strategi Belajar Mengajar 104.
} 
adalah untuk meningkatkan mutu pembelajaran,akan tercapai jika tercapainya tujuan pembelajaran.

Menurut Suharsimi Arikunto yang dikutip oleh Syaiful Bahri Djamarah \& Aswan Zain, ${ }^{20}$ berpendapat bahwa tujuan pengelolaan kelas adalah agar setiap anak di kelas dapat bekerja dengan tertib sehingga segera tercapai tujuan pengajaran yang efektif dan efisien. Menurutnya, sebagai indikator dari sebuah kelas yang tertib adalah apabila:

1. Setiap anak terus bekerja, artinya tidak ada anak yang terhenti karena tidak tahu ada tugas yang harus dilakukan atau tidak dapat melakukan tugas yang diberikan kepadanya.

2. Setiap anak terus melakukan pekerjaan tanpa membuang waktu, artinya setiap anak akan bekerja secepatnya supaya lekas menyelesaikan tugas yang diberikan kepadannya. Apabila ada anak yang walaupun tahu dan dapat melaksanakan tugasnya, tetapi mengerjakannya kurang bergairah dan mengulur waktu bekerja, maka kelas tersebut dikatakan tidak tertib.

Prinsip-prisip pengelolaan kelas merupakan konsep-konsep yang harus diterapkan di dalam proses pembelajararan. Seorang guru akan dapat melaksanakan tugasnya dengan baik apabila ia dapat menerapkan cara mengajar yang sesuaidengan prinsip-prinsip tersebut. Penting bagi guru untuk mengetahui dan menguasai prinsip-prinsip pengelolaan kelas seperti yang diungkapkan oleh Syaiful Bahri Djamarah dan Aswan Zain, ${ }^{21}$ ada enam prinsip dalam pengelolaan kelas yaitu:.

1. Hangat dan antusias

Hangat dan antusias diperlukan dalam proses belajar mengajar. Guru yang hangat dan akrab dengan anak didik selalu menunjukkan antusias pada tugasnya atau pada aktifitasnya, dengan demikian maka guru akan berhasil dalam mengimplementasikan pengelolaan kelas.

2. Tantangan

Penggunaan kata-kata, tindakan, cara kerja atau bahan-bahan yang menantang akan mengakibatkan gairah anak didik untuk belajar, sehingga mengurangi kemungkinan tingkah laku anak didik yang menyimpang.

3. Bervariasi

Penggunaan alat atau media, atau alat bantu, gaya mengajar guru, pola interaksi guru dan anak didik akan mengurangi munculnya gangguan,meningkatkan perhatian anak didik. Apabila penggunaan bervariasi, sesuai dengan kebutuhan sesaat.

4. Keluwesan

Keluwasan tingkah laku guru untuk mengubah strategi mengajarnya dapat mencegah kemungkinan munculnya gangguan pada anak didik serta dapat menciptakan iklim belajar mengajar yang efektif.

5. Penekanan pada hal-hal yang positif

\footnotetext{
${ }^{20}$ Syaiful Bahri Djamarah \& Aswan Zain, Strategi Belajar Mengajar.

${ }^{21}$ Syaiful Bahri Djamarah \& Aswan Zain, Strategi Belajar Mengajar... 
Pada dasarnya mengajar dan mendidik, guru harus menekankan pada hal-hal yang positif dan menghindari pemusatan perhatian anak didik pada hal-hal negatif.

6. Penanaman pada disiplin diri

Tujuan akhir dari pengelolaan kelas adalah anak didik dapat mengembangkan disiplin diri sendiri. Karena itu, gurusebaiknya selalu mendorong anak didikuntuk melaksanakan disiplin diri sendiri dan guru hendaknya menjadi teladan mengenai pengendalian diri dan pelaksanakan tanggung jawab.

Menurut Najib Khalil al-Amir yang dikutip oleh Abuddin Nata, ${ }^{22}$ di dalam melakukan pengelolaan kelas dijumpai adanya berbagai pendekatan yang digunakan oleh guru, yang antara lain pendekatan kekuasaan, ancaman, kebebasan, resep, pengajaran, perubahan tingkah laku, emosidan hubungan sosial, proses kelompokelektis atau pluralistik. Berbagai pendekatan ini muncul, karena pengelolaan kelas bukanlah masalah yang berdiri sendiri, tetapi terkait dengan berbagai faktor. Permasalahan peserta didik sebagaimana tersebut di atas, merupakan faktor utama yang terkait langsung dengan pengelolaan kelas. Hal ini terjadi, karena pengeloalaan kelas yang dilakukan dengan berbagai pendekatan apa pun, pada intinya ditujukan untuk meningkatkan kegairahan peserta didik dalam kegitan belajar mengajar, baik secara individual maupunkelompok. Di dalam pengelolaan kelas terdapat hubungan, perintah, interaksi dan lainnya antara guru dan murid, dan antara murid dan antara masyarakat dan guru.

Menurut Abuddin Nata, ${ }^{23}$ pengelolaan kelas mempunyai berbagai macam pendekatan sebagai berikut :

1. Pendekatan Kekuasaan

Pengelolaan kelas dengan pendekatan kekuasaan sebagaimana tersebut di atas, diartikan sebagai suatu proses untuk mengontrol tingkah laku anak didik. Guru yang menggunakan pendekatan ini dapat menggunakan berbagai strategi antara lain: a). membuat dan menjalankan peraturan; b). mengeluarkan pengarahan dan perintah, c) memberikan teguran atau perintah; d). mengadakan pengawasan. Peran guru di sini adalah menciptakan dan mempertahankan situasi disiplin dalam kelas. Kedisiplinan tersebut menuntut adanya suatu kekuatan yang dapat menekan anak didik untuk mentaatinya. Di dalamnya terdapat kekuasaan dalam norma yang mengikat untuk ditaati anggota kelas. Melalui kekuasaan dalam norma itulah guru mendekatinya.

\section{Pendekatan Ancaman}

Adapun pengelolaan kelas dengan pendekatan ancaman atau intimidasi, adalah suatu proses untuk mengontrol tingkah laku anak didik yang dilakukan dengan cara memberikan ancaman, seperti melarang, mengejek, menyindir, memaksa, dan sebagainya. Pendekatan ini pada dasarnya sama dengan pendekatan otoriter dan kekuasaan sebagaimana

\footnotetext{
${ }^{22}$ Abuddin Natta, Persepektif Islam Tentang ............., 342.

${ }^{23}$ Abuddin Natta, Persepektif Islam Tentang..... 
tersebut di atas. Dengan pendekatan ini, setiap perbuatan peserta didik yang dianggap menyimpang dapat diatasi dengan cara mengintimidasi. Cara-cara intimidasi tersebut antara lain dengan melarang, memaksa, mengancam, mentertawakan, menyindir, mencela, dan sebagainya.

3. Pendekatan Kebebasan

Pengelolaan kelas dengan pendekatan kebebasan ini adalah mengupayakan terciptanya kebebasan pesrta didik dalam mengerjakan sesuatu, kapan dan dimana saja. Pengelolaan kelas dengan kebebasan pendekatan ini didasarkan pada sebuah asumsi, bahwa pengajaran dapat diartikan sebagai suatu proses yang membantu peserta didik agar merasa bebas untuk mengerjakan sesuatu kapan saja dan dimana saja. Peran guru adalah mengusahakan semaksimal mungkin kebebasan anak didik.

4. Pendekatan Resep

Pengelolaan kelas dengan pendekatan resep adalah sebuah pengelolaan dengan memberi suatu daftar yang dapatmenggambarkan apa yang harus dan apa yang tidak boleh dikerjakan oleh guru dalam menghadapi sebuah masalah atau situasi yang terjadi dalam kelas. Dalam daftar ini digambarkan tahap demi tahapapa yang harus dikerjakan oleh guru.Posisi dan peran guru hanyalah mengikuti petunjuk penggunaannya yang telah ditetapkan.

5. Pendekatan Pengajaran

Pengelolaan kelas dengan pendekatan pengajaran, adalah pengelolaan kelas yang didasarkan atas suatu anggapan bahwa dalam suatu perencanaan dan pelaksanaan akan mencegah munculnya masalah tingkah laku anak didik, dan memecahkan masalah itu bila tidak bisa dicegah. Pendekatan ini menganjurkan tingkah laku guru dalam mengajar untuk mencegah dan menghentikan tingkah laku anak didik yang kurang baik. Dalam hubungan ini peranan guru adalah merencanakan dan mengimplementasikan pelajaran yang baik.

6. Pendekatan Pengubahan Tingkah Laku

Dalam pada itu, melalui pendekatan perubahan tingkah laku, pengelolaan kelas diartikan sebagai suatu proses untuk mengubah tingkah laku anak didik. Dalam hal ini peranan guru adalah mengembangkan tingkah laku anak didik yang baik, dan mencegah tingkah laku yang kurang baik.

7. Pendekatan Emosi dan Hubungan Sosial

Pengelolaan kelas, dengan pendekatan emosi dan hubungan sosial (socio-emotional climate approach) adalah pengelolaan kelas yang didasarkan pada pendekatan psikologi klinisdan konseling (penyuluhan). Pendekatan ini didasarkan bahwa: a) proses belajar mengajar yang efektif mensyaratkan adanya iklim sosio-emososionalyang baik antara guru dan peserta didik, dan antara peserta didik dengan peserta didik lainnya; dan b)guru menduduki posisi terpenting bagi terbentuknya sosio-emosional yang baik.

Dengan pendekatan ini, pengelolaan kelas di lihat sebagai proses menciptakan iklim atau suasana emosional dan hubungan sosial yang 
positif dalam kelas. Suasana emosional dan hubungan sosial yang positif artinya bahwa didalamnya terdapat hubungan yang baik dan positif antara guru dan anak didik, atau antara anak didik dengan anak didik. Dalam hubungan ini, guru bertindak seagai kunci terhadap pembentukan hubungan pribadi itu, dan peranannya adalah menciptakan hubungan pribadi sehat.

8. Pendekatan Kelompok

Pendekatan proses kelompok dimaksudkan untuk menciptakan kelas sebagai suatu sistem sosial, dengan menempatkan proses kelompoksebagai yang paling utama. Dalam kaitan ini guru bertindak sebagai orang yang mengusahakan agar perkembangan dan pelaksanaan proses kelompok ini dapat bejalan secara efektif. Dalam proses kelompok ini guru mengelompokan anak didik kedalam beberapa kelompok dengan berbagai pertimbangan individual sehingga tercipta kelas yang bergairah, menyenangkan, dan menggembirakan.

9. Pendekatan Elektis

Yang terakhir, adalah pendekatan elektis (electik approach) yang menekankan pada potensialitas, kreatifitas, dan inisiatif wali/guru kelas dalam memilih berbagai pendekatan tersebut berdasarkan situasi yang dihadapinya.

\section{Faktor-Faktor Pendukung dan Penghambat dalam Pengelolaan Kelas \\ 1. Faktor-Faktor Pendukung Pengelolaan Kelas}

Menurut Hadari Nawawi ${ }^{24}$ faktor yang mendukung pengelolaan kelas antara lain:

a) Kurikulum

Sebuah kelas tidak boleh sekedar diartikan sebagai tempat siswa berkumpul untuk mempelajari sejumlah ilmu pengetahuan.Demikian juga sebuah sekolah bukanlah sekedar sebuah gedung tempat murid mencari dan mendapatkan ilmu pengetahuan.

Sekolah dan kelas diselenggarakan untuk memenuhi kebutuhan masyarakat dalam mendidik anak-anak yang tidak hanya harus didewasakan dari segi intelektualitasnya saja, akan tetapi dalam seluruh aspek kepribadiannya. Untuk itu bagi setiap tingkat dan jenis sekolah diperlukan kurikulum yang mampu memenuhi kebutuhan masyarakat yang semakin kompleks dalam perkembangannya. Kurikulum yang dipergunakan di sekolah sangat besar pengaruhnya terhadap aktifitas kelas dalam mewujudkan proses belajar mengajar yang berdaya guna bagi pembentukan pribadi siswa.

Sekolah yang kurikulumnya dirancang secara tradisional akan mengakibatkan aktifitas kelas akan berlangsung secara statis. Sedangkan sekolah yang diselenggarakan dengan kurikulum modern pada dasarnya akan mampu menyelenggarakan kelas yang bersifat dinamis.

${ }^{24}$ Hadari Nawawi, Metode Penelitian Bidang Sosial (Yogyakarta: Gadjah Mada University Press, 1998), 116. 
Kedua kurikulum di atas kurang serasi dengan kondisi masyarakat Indonesia yang memiliki pandangan hidup Pancasila. Di satu pihak kurikulum tradisional yang berpusat pada guru akan diwarnai dengan sikap otoriter yang mematikan inisiatif dan kreatifitas murid. Di pihak lain kurikulum modern yang menekankan kebebasan atas dasar demokrasi liberal sehingga tidak memungkinkan diselenggarakan secara efektif kegiatan belajar secara klasikal untuk pengembangan pribadi sebagai makhluk sosial dan makhluk Tuhan Yang Maha Esa.

Oleh karena itu diperlukan usaha untuk mengintegrasikan kedua kurikulum tersebut dalam kehidupan lembaga formal di Indonesia agar serasi dengan kebutuhan dan dinamika masyarakat.Kurikulum harus dirancangkan sebagai pengalaman edukatif yang menjadi tanggung jawab sekolah dalam membantu anak-anak mencapai tujuan pendidikannya, yang diselenggarakan secara berencana, sistematik, dan terarah serta terorganisir.

b) Gedung dan Sarana Kelas

Perencanaan dalam membangun sebuah gedung untuk sebuah sekolah berkenaan dengan jumlah dan luas setiap ruangan, letak dan dekorasinya yang harus disesuaikan dengan kurikulum yang dipergunakan.Akan tetapi karena kurikulum selalu dapat berubah sedang ruangan atau gedung bersifat permanen, maka diperlukan kreatifitas dalam mengatur pendayagunaan ruang/gedung.

Sekolah yang mempergunakan kurikulum tradisional pengaturan ruangan bersifat sederhana karena kegiatan belajar mengajar diselenggarakan di kelas yang tetap untuk sejumlah murid yang sama tingkatannya. Sekolah yang mempergunakan kurikulum modern, ruangan kelas diatur menurut jenis kegiatan berdasarkan program-progam yang telah dikelompokkan secara integrated. Sedangkan sekolah yang mempergunakan kurikulum gabungan pada umumnya ruangan kelas masih diatur menurut keperluan kelompok murid sebagai suatu kesatuan menurut jenjang dan pengelompokan kelas secara permanen.

c) Guru

Program kelas tidak akan berarti bilamana tidak diwujudkan menjadi kegiatan. Untuk itu peranan guru sangat menentukan karena kedudukannya sebagai pemimpin pendidikan diantara murid-murid dalam suatu kelas. Guru adalah seseorang yang ditugasi mengajar sepenuhnya tanpa campur tangan orang lain.

Setiap guru harus memahami fungsinya karena sangat besar pengaruhnya terhadap cara bertindak dan berbuat dalam menunaikan pekerjaan sehari-hari di kelas dan di masyarakat. Guru yang memahami kedudukan dan fungsinya sebagai pendidik profesional, selalu terdorong untuk tumbuh dan berkembang sebagai perwujudan perasaan dan sikap tidak puas terhadap pendidikan.Persiapan yang harus diikuti, sejalan dengan ilmu pengetahuan dan teknologi. ${ }^{25}$

d) Murid

${ }^{25}$ Hadari Nawawi, Metode Penelitian 121 
Murid merupakan potensi kelas yang harus dimanfaatkan guru dalam mewujudkan proses belajar mengajar yang efektif. Murid adalah anak-anak yang sedang tumbuh dan berkembang, dan secara psikologis dalam rangka mencapai tujuan pendidikannya melalui lembaga pendidikan formal, khususnya berupa sekolah.Murid sebagai unsur kelas memiliki perasaan kebersamaan yang sangat penting artinya bagi terciptanya situasi kelas yang dinamis.

Setiap murid memiliki perasaan diterima terhadap kelasnya agar mampu ikut serta dalam kegiatan kelas. Perasaan diterima itu akan menentukan sikap bertanggung jawab terhadap kelas yang secara langsung berpengaruh pada pertumbuhan dan perkembangannya masing-masing. ${ }^{26}$

e) Dinamika Kelas

Kelas adalah kelompok sosial yang dinamis yang harus dipergunakan oleh setiap guru kelas untuk kepentingan murid dalam proses kependidikannya. Dinamika kelas pada dasarnya berarti kondisi kelas yang diliputi dorongan untuk aktif secara terarah yang dikembangkan melalui kreativitas dan inisiatif murid sebagai suatu kelompok.Untuk itu setiap wali atau guru kelas harus berusaha menyalurkan berbagai saran, pendapat, gagasan, keterampilan, potensi dan energi yang dimiliki murid menjadi kegiatan-kegiatan yang berguna.

Dengan demikian kelas tidak akan berlangsung secara statis, rutin dan membosankan. Kreativitas dan inisiatif yang baik perwujudannya tidak sekedar terbatas di dalam kelas sendiri, tetapi mungkin pula dilaksanakan bersama kelas-kelas yang lain atau oleh seluruh kelas. Setiap kelas harus dilihat dari dua segi. Pertama, kelas sebagai satu unit atau satu kesatuan utuh yang dapat mewujudkan kegiatan berdasarkan program masing-masing. Kedua, kelas merupakan unit yang menjadi bagian dari sekolah sebagai suatu organisasi kerja atau sebagai subsistem dari satu total sistem. Kedua sudut pandang itu harus sejalan dalam arti semua kegiatan kelas yang dapat ditingkatkan menjadi kegiatan sekolah harus dimanfaatkan sebaik-baiknya bagi semua murid. ${ }^{27}$

\section{Faktor-faktor Penghambat Pengelolaan Kelas}

Keanekaragaman masalah perilaku siswa itu menimbulkan beberapa masalah dalam pengelolaan kelas. Menurut Made Pidarta yang dikutip Syaiful Bahri Djamarah \& Aswan Zain ${ }^{28}$ bahwa masalah-masalah yang berhubungan dengan perilaku siswa adalah:

a. Kurang kesatuan, dengan adanya kelompok-kelompok, dan pertentangan jenis kelamin.

b. Tidak ada standar perilaku dalam bekerja kelompok, misalnya ribut, bercakap-cakap, pergi kesana kemari, dan sebagainya.

c. Reaksi negatif terhadap anggota kelompok, misalnya ribut, bermusuhan, mengucilkan, merendahkan kelompok bodoh, dan sebagainya.

\footnotetext{
${ }^{26}$ Hadari Nawawi, Metode Penelitian, .........., 127.

${ }^{27}$ Hadari Nawawi, Metode Penelitian, ............, 130.

${ }^{28}$ Syaiful Bahri Djamarah \& Aswan Zain, Strategi Belajar Mengajar.
} 195. 
d. Kelas mentoleransi kekeliruan-kekeliruan temannya ialah menerima dan mendorong perilaku siswa yang keliru.

e. Mudah mereaksi negatif/terganggu, misalnya didatangi monitor, tamutamu, iklim yang berubah, dan sebagainya.

f. Moral rendah, permusuhan, agresif, misalnya dalam lembaga alat-alat belajar kurang, kekurangan uang dan sebagainya.

g. Tidak mampu menyesuaikan dengan lingkungan yang berubah, seperti tugas-tugas tambahan, anggota kelas yang baru, situasi baru, dan sebagainya.

Lois V. Johnson Mary A. Bany dalam Ahmad Rohani ${ }^{29}$ mengemukakan enam kategori masalah kelompok dalam pengelolaan kelas. sebagai berikut:

a. Kelas kurang kohesif;

b. Kelas mereksi negative terhadap salah seorang anggotanya;

c. "membesarkan" hati anggota kelas yang justru melanggar norma kelompok;

d. Kelompok cenderung mudah dialihkan perhatiannya dari tugas yang tengah digarap.

e. Semangat kerja rendah;

f. Kelas kurang mampu menyesuaikan diri dengan keadaan baru;

Dalam pelaksanaan pengelolaan kelas akan dimulai berbagai faktor penghambat. Hambatan tersebut bisa datang dari guru sendiri, dari peserta didik, lingkungan keluarga ataupun karena faktor fasilitas. ${ }^{30}$

a. Guru

Guru sebagai seorang pendidik, tentunya ia juga mempunyai banyak kekurangan. Kekurangan-kekurangan itu bisa menjadi penyebab terhambatnya kreativitas pada diri guru tersebut. Diantara hambatan itu ialah:

1. Tipe kepemimpinan guru

Sikap kepemimpinan guru yang otoriter dan kurang demokratis akanmembuat anakbersikap pasif peserta atau agresif dan hal inilah yang menjadi masalah dalam pengelolaan kelas.

2. Format yang monoton

Format belajar yang monoton dapat menimbulkan kebosanaan, frustasi atau kecewasi anak didik hal inilah yang akan menjadisember pelanggaran disiplin.

3. Kepribadian guru

Seorang guru itu dituntut bersikap hangat, adil, objektif dan fleksibel sehingga tercipta susana emosional yang menyenangkan dalam proses belajar mengajar.

4. Pengetahuan guru

Terbatasnya pengetahuan guru terutama masalah pengelolaan dan pendekatan pengelolaan, baik yang sifatnya teoritis maupun pengalaman praktis, sudah barang tentu akan mengahambat perwujudan pengelolaan kelas dengan sebaikbaiknya. Oleh karena itu, pengetahuan guru tentang pengelolaan kelas sangat diperlukan.

5. Pemahaman guru tentang peserta didik ${ }^{29}$ Ahmad Rohani, Pengelolaan Pengajaran (Jakarta: PT Rineka Cipta, 2013), 146.
${ }^{30}$ Ahmad Fauzi, Manajemen Pembelajaran, .........., 59-60. 
Terbatasnya kesempatan guru untuk memahami tingkah laku peserta didik dan latar belakangnya dapat disebabkan karena kurangnya usaha guru untuk dengan sengaja memahami peserta didik dan latar belakangnya.Karena pengelolaan pusat belajar harus disesuaikan dengan minat, perhatian, dan bakat para siswa, maka siswa yang memahami pelajaran secara cepat, rata-rata, dan lamban memerlukan pengelolaan secara khusus menurut kemampuannya. Semua hal di atas memberi petunjuk kepada guru bahwa dalam proses belajar mengajar diperlukan pemahaman awal tentang perbedaan siswa satu sama lain.

b. Peserta didik

Anak didik itu mempunyai hak dan kewajiban, maka sebagai anak didik mereka harussadar kalau mereka itu mengganggu temannya yang sedang belajar berarti tidak melaksanakan kewajiban.

Pembiasaan mengikuti tata tertib sekolah itu merupakan hak mereka maka apabila tidak mereka penuhi berarti mereka tidak sadar akan kewajiban mereka.

c. Keluarga

Tingkah laku peserta didik di dalam kelas merupakan pencerminan keadaan keluarganya. Sikap otoriter orang tua akan tercermin dari tingkah laku peserta didik yang agresif dan apatis. Problem klasik yang dihadapi guru memang banyak berasal dari lingkungan keluarga.Kebiasaan yang kurang baik di lingkungan keluarga seperti tidak tertib, tidak patuh pada disiplin, kebebasan yang berlebihan atau terlampau terkekang merupakan latar belakang yang menyebabkan peserta didik melanggar di kelas.

d. Fasilitas

Fasilitas yang ada merupakan faktor penting upaya guru memaksimalkan programnya, fasilitas yang kurang lengkap akan menjadi kendala yang berarti bagi seorang guru dalam beraktivitas. Kendala tersebut ialah :

1. Jumlah peserta didik di dalam kelas yang sangat banyak

2. Besar atau kecilnya suatu ruangan kelas yang tidak sebanding dengan jumlah siswa.

3. Keterbatasan alat penunjang mata pelajaran

\section{Meningkatkan Efektivitas Proses Pembelajaran}

Efektivitas berarti keberhasilan, manjur, atau mujarab. Dan proses pembelajaran adalah proses interaksi peserta didik dengan pendidik dan sumber belajar pada suatu lingkungan belajar. Pembelajaran merupakan bantuan yang diberikan pendidik agar dapat terjadi proses pemerolehan ilmu dan pengetahuan, penguasaan kemahiran dan tabiat, serta pembentukan sikap dan kepercayaan pada peserta didik. Dengan kata lain, pembelajaran adalah proses untuk membantu peserta didik agar dapat belajar dengan baik.

Pembelajaran itu berasal dari kata belajar yang dikasih kata imbuhan yaitu pem-an.Belajar adalah kegiatan yang dilakukan oleh seseorang agar memilki kompetensi berupa keterampilan dan pengetahuan yang 
diperlukan. ${ }^{31}$ Sedangkan pembelajaran sendiri dapat diartikan sebagai upaya untuk membelajarkan siswa, dalam pengertian ini secara implisit dalam pembelajaran terdapat kegiatan memilih, menetapkan mengembangkan metode untuk mencapai hasil yang diinginkan.Jadimeningkatkanefektivitas pembelajaran adalah merangsang dan mensukseskan proses belajar dan untuk mencapai tujuan mengandung pengertian keberhasilan pembelajarandalam proses belajar.

Efektivitas pembelajaran adalah hasil guna yang diperoleh setelah pelaksanaan proses pembelajaran.Sedangkan pembelajaran merupakan komunikasi dua arah, dimana kegiatan guru sebagai pendidik harus mengajar dan murid sebagai terdidik yang belajar. Jadipeningkatan/meningkatkan efektivitas proses pembelajaran adalah sebuah cara atau usaha yang dilakukan untukmendapatkan keterampilan atau kemampuan menjadi lebih baik yang diperoleh setelah pelaksanaan proses pembelajaran.

Menurut Pupuh Fathurrohman dan M.Sobry Sutikno, ${ }^{32}$ bahan kegitan belajar mengajar mengandung sejumlah komponen yang meliputi tujuan, bahan pebelajaran, kegiatan pelajaran, kegiatan belajar mengajar, metode, alat dan sumber, serta evaluasi.

\section{a. Tujuan}

Tujuan merupakan suatu cita-cita yang ingin dicapai dari pelaksanaan pembelajaran. Tidak ada suatu pembelajaran yang diprogamkan tanpa tujuan, karena hal ini merupakan kegiatan yang tidak memiliki kepastian dalam menentukan arah, target akhir dan prosedur yang dilakukan

b. Bahan pelajaran

Bahan/materi merupakan medium untuk mencapai tujuan pengajaran yang "dikonsumsi" oleh peserta didik. Bahan ajar merupakan materi yang terus berkembang secara dinamis seiring dengan kemajuan dan tuntutan perkembangan masyarakat. Bahan ajar yang diterimah anak didik harus mampu merespons setiap perubahan dan mengantisipasi setiap perkembangan yang akan terjadi di masa yang akan datang.

c. Kegiatan Pembelajaran

Dalam kegiatan pembelajaran, guru dan peserta didik terlibat dalam sebuah interaksi dengan bahan pelajaran sebagai mediumnya. Dalam interaksi itu peserta didiklah yang lebih aktif, bukan guru.Keaktifan anak didiktentu mencangkupkegiatan fisik dan mental, individual dan kelompok. Oleh karena itu interaksi dikatakan maksimal bila bila terjadi antara guru dengan semua peserta didik, antara peserta didik dengan guru, antara peserta didik dengan peserta didik, peserta didik dengan bahan dan media pembelajaran, bahkan peserta didik dengan dirinya sendiri, namun tetap dalam kerangka mencapai tujuan yang telah ditetapkan bersama.

d. Metode

\footnotetext{
${ }^{31}$ Benny Pribadi, Model Desain Sistem Pembelajaran (Jakarta: Dian Rakyat, 2009), 6.

${ }^{32}$ Pupuh Fathurrahman \& M. Sobry Sutikno, Strategi Belajar Mengajar.................., $13-$ 18.
} 
Metode merupakan suatu cara yangdipergunakan untuk mencapai tujuan yang telah ditetapkan. Dalam kegiatan belajar mengajar, metide sangat diperlukan oleh guru, dengan penggunaan yang bervariasi sesuai dengan tujuan yang ingin dicapai.Menguasai metode mengajar merupakan keniscayaan, sebab seorang guru tidak dapat mengajar dengan baik apabila tidak menguasai metode.

e. Alat

Alat merupakan segala sesuatu yang dapat digunakandalam rangka mencapai tujuan pengajaran. Alat dapat dibagi menjadi dua macam, yaitu alat verbal dan alat bantu non verbal. Alat verbal berupa suruhan, perintah, larangan dan sebagainya. Sebagai alat Bantu non verbal berupa globe, papan tulis, buku tulis, batu kapur, gambar, diagram, slide, video dan sebagainya.

f. Sumber Pelajaran

Sumber pelajaranadalah segala sesuatu yang dapat dipergunakan sebagai tempat dimana bahan pengajaran bisa didapatkan. Roestiyah N.K. (1989) yang dikutip oleh Pupuh Fathurrohman dan M. Sobry Sutikno ${ }^{33}$, mengatakan bahwa sumber-sumber belajar itu adalah:

1) Manusia (dalam keluarga, sekolah dan masyarakat);

2) Buku/perpustakaan;

3) Media massa (majalah, surat kabar, radio, tv, dan lain lain)

4) Lingkungan alam, social, dan lain-lain;

5) Alat pelalajaran (buku pelajaran, peta, gambar, kaset, tape, papan tulis, kapur, spidol, dan lain-lain);

6) Museum (tempat penyimpanan benda-benda kuno).

g. Evaluasi

Istilah evaluasi berasal dari bahasa Inggris, yaitu evaluasion. Menurut M. Sukardi, ${ }^{34}$ bahwa evaluasi pembelajaran merupakan inti bahasan evaluasi yang kegiatannya dalam lingkup kelas atau dalam lingkup proses belajar mengajar. Evaluasi selalu memegang peranan yang sangat penting dalam segala bentuk pengajaran yang efektif. Menurut S. Nasution, ${ }^{35}$ dengan evaluasi diperoleh balikan atau feedblack yang dipakai untuk memperbaiki dan merefisi bahan atau metode pengajaran, atau untuk menyesuaikan bahan dengan perkembangan ilmu pengetahuan. Evaluasi berguna untuk mengetahui hingga manakah siswa telah mencapai tujuan pelajaran yang telah ditentukan.

1) Tujuan evaluasi secara umum, yakni:

a) Mengumpulkan data-data yang membuktikan taraf kemajuan taraf kemajuan murid dalam mencapai tujuan yang diharapkan.

b) Memungkinkan pendidik/guru menilai aktivitas/pengalaman yang didapat siswa dalam pembelajaran.

c) Menilai metode mengajar. ${ }^{36}$

\footnotetext{
${ }^{33}$ Pupuh Fathurrahman \& M. Sobry Sutikno, Strategi Belajar Mengajar ................... 32.
}

${ }^{34}$ M. Sukardi, Evaluasi pendidikan Prinsip \& Operasionalnya(Jakarta: PT. Bumi aksara, 2011), 5 .

${ }^{35}$ S. Nasution, Berbagai Pendekatan dalam Proses Belajar \& Mengajar(Jakarta:PT. Bumi Aksara, 2013), 78.

${ }^{36}$ Pupuh Fathurrahman \& M. Sobry Sutikno, Strategi Belajar Mengajar. 65 . 
2) Tujuan Khusus

a) Untuk mengetahui apakah dalam pembelajaran ini siswa sudah belajar secara efektif tertuju pada pencapaian prestasi belajar yang maksimal.

b) Untuk mengumpulkan informasi tentang kinerja guru dalam pembelajaran ini, apakah guru sudah berperan aktif sebagai pengarah, pengajar motivator, dan pembimbing siswa secara maksimal.

c) Untuk mengetahui melalui pencermatan terhadap materi yang disampaikan dalam mata pelajaran, apakah sudah mengacu pada kurikulum, dan dipilih sedemikian rupa sehingga merupakan objek yang tepat dipelajari oleh siswa.

d) Untuk memperoleh secara rinci mengenai hal-hal yang ada dalam pelaksanaan pembelajaran sudah didukung oleh sarana yang tepat, mencukupi dan tersedia ketika akan digunakan.

e) Untuk mengetahui melalui melaksanakan sendiriapakah dalam pembelajaran guru sudah melakukan pengelolaan kelas secara benar, baik penataan fisik maupun pengaturan ruang duduk siswa, sehingga dimungkinkan adanya situasi adanya pembelajaran yang kondusif dan interaksi yang efektif.

f) Untuk mengumpulkan informasi tentang lingkungan ketika siswa belajar, apakah sudah sedemikian nyaman sehingga mendukung ketentraman dan kelancaran siswa dalam belajar.

\section{E. Kesimpulan}

Proses pembelajaran merupakan inti dari proses pendidikan formal dengan guru sebagai pemeran utama. Guru sangat menentukan suasana pembelajaran di dalam kelas. Guru yang kompeten akan lebih mampu dalam menciptakan lingkungan belajar yang efektif dan efisien di dalam kelas. Pembelajaran yang efektif memudahkan siswa belajar sesuatu yang bermanfaat, seperti fakta keterampilan, nilai, konsep, cara hidup serasi dengan sesama, atau sesuatu hasil belajar yang diinginkan sehingga hasil belajar siswa berada pada tingkat yang optimal. Keberhasilan tersebut, dipengaruhi banyak faktor terutama terletak pada pengajar(guru) dan yang diajar (siswa), yang berkedudukan sebagai pelaku dan subyek dalam proses tersebut.

Oleh karena itu, pengelolaan sekolah perlu menciptakan suasana gembira atau menyenangkan di lingkungan sekolah melalui pengelolaan kelas. karena, dengan menjalin keakraban antara guru-siswa, maka guru dapat mengarahkan siswa dengan lebih mudah untuk mendorong dan memotivasi semangat belajar siswa. Disamping itu, juga efektivitas belajar dapat ditingkatkan melalui berabagai upaya. Pembelajaran menyenangkan satu diantara cara yang dapat dilakukan untuk mencapai efektivitaspemebelajaran. Pembelajaran menyenangkan adalah pembelajaran dimana interaksi antara guru dan siswa, lingkungan fisik, dan suasana memberikan peluang terciptanya kondisi yang kondusif untuk belajar. 
Keberhasilan atau kegagalan dalam proses pembelajaran merupakan sebuah ukuran atas proses pembelajaran. Apabila merujuk pada rumusan operasional keberhasilan belajar, maka belajar dikatakan berhasil apabila diikuti ciri-ciri sebagai berikut :

1. Daya serap terhadap bahan pengajaran yang diajarkan mencapai prestasi tinggi, baik secara individu maupun kelompok.

2. Perilaku yang digariskan dalam tujuan pengajaran telah dicapai oleh siswa baik secara individual maupun kelompok.

3. Terjadinya proses pemahaman materi secara sekuensional mengantarkan materi tahap berikutnya.

\section{DAFTAR PUSTAKA}

Arikunto, Suharsimi. 1992. Pengelolaan Kelas dan Siswa Sebuah Pendekatan Evaluatif. Jakarta: Rajawali Press.

Darmasya. 2010. Strategi Pembelajaran Menyenangkan Dengan Humor. Jakarta:PT. Bumi Aksara.

Djamarah, Syaiful Bahri \&Aswan Zain. 2010. Strategi Belajar Mengajar. Jakarta: Rineka Cipta.

Fathurohman, Pupuh \&Sobry Sukitno. 2011. Strategi Belajar Mengajar Melalui Konsep Umum \& Konsep Islami. Bandung: Refika Sditama.

Fauzi, Ahmad. 2013. Manajemen Pembelajaran. Yogyakarta:Deepublish.

Gintings, Abdorrakhman. 2008. Esensi Praktis Belajar \& Pembelajaran. Bandung: Humaniora.

Hamalik, Oemar. 2009. Perencanaan Pengajaran Berdasarkan PendekatanSistem. Jakarta:BumiAksara.

Hamdani. 2011. Strategi Balajar Mengajar. Bandung: CV Pustaka Setia.

Hamzah B. Uno. 2008. Model Pembelajaran Menciptakan Proses Belajar Mengajar yang Kreatif dan Efektif. Jakarta: PT Bumi Aksara.

Madjid, Abdul. 2011. Perencanaan Pembelajaran Mengembangkan Standar Kompetensi Guru. Bandung: PT Remaja Rosdakarya.

Nasution, S.2013. Berbagai Pendekatan dalam Proses Belajar \& Mengajar. Jakarta : PT. Bumi Aksara.

Natta, Abuddin. 2011. Persepektif Islam Tentang Strategi Pembelajaran. Jakarta: Prenada Media Group.

Nawawi, Hadari. 1998. Metode Penelitian Bidang Sosial. Yogyakarta: Gadjah Mada University Press.

Pidarta, Made. 2010.Pengelolaan Kelas. Surabaya: Usaha Nasional.

Pribadi, Benny. 2009. Model Desain Sistem Pembelajaran. Jakarta: Dian Rakyat. 
Rohani, Ahmad. 2013. Pengelolaan Pengajaran. Jakarta: PT Rineka Cipta.

Sarwiji, Bambang. 2006. Kamus Pelajar Bahasa Indonesia.Ganeca Exact.

Sukardi, M. 2011. Evaluasi pendidikan Prinsip \& Operasionalnya. Jakarta: PT. Bumi aksara.

Sutikno, M. Sobry. 2008. Belajar dan Pembelajaran. Bandung: Prospect. 